\title{
Accounting Risks in the Subjects of Business Systems
}

\author{
Maria V. Stafievskaya ${ }^{1}$, Lidia V. Nikolayeva ${ }^{1}$, Svetlana G. Kreneva ${ }^{1}$, Ramziya K. Shakirova ${ }^{1}$, Olesya A. \\ Semenova ${ }^{1}$, Tamara P. Larionova ${ }^{1} \&$ Nicholas V. Filyushin ${ }^{1}$ \\ ${ }^{1}$ Mari State University, Yoshkar-Ola, Russia \\ Correspondence: Maria V. Stafievskaya, Mari State University, Republic of Mari El, Russia. Tel: \\ 8-927-871-3268. E-mail: stafievskaya16@mail.ru
}

\author{
Received: February 21, 2015 Accepted: March 15, 2015 Online Published: April 28, 2015 \\ doi:10.5539/res.v7n8p127 \\ URL: http://dx.doi.org/10.5539/res.v7n8p127
}

\begin{abstract}
The study of economic activity of subjects of business systems shows that the emergence of risk is a consequence of uncertainty, which is characteristic manifests itself in the formation of the accounting (financial) statements. Today, due to the financial crisis, the relevance of financial statements is constantly increasing. Accounting is the main data base, which accurately reflect the financial condition of the subject and allows you to make effective economic decisions. All of the economic risks it is necessary to identify assess and take into accounting because the lack of information may become a viable source of losses and will distort the reporting of data on financial results. Today the Russian economies have different risks, but their accounting is missing. This leads to a direct distortion of accounting data and subsequently can lead to bankruptcy. Not currently developed methods for the assessment of the accounting risk through the mechanism of redundancy. It is necessary to reconsider the practice of ignoring actual accounting risks in accounting. In this regard, there is a need to study accounting risks, classification, valuation, accounting as its objects. The urgency of the problems and determined the research topic. In the article the author's technique of creating information accounting software accounting risks commercial organizations, as well as the developed form of working documents to reflect the obtained results with the purpose of organization of analytical and synthetic accounting. The study aims to develop a methodology for the inclusion in the financial statements of commercial entities probable losses that are associated with the effects of accounting risks, as well as to create account registers, which will improve the reliability of data on financial reserves, information, and control over its use. Overall results of the study are upgrading internal system of accounting organization risks.
\end{abstract}

Keywords: risks, uncertainties, accounting risks, reserves, professional judgment, internal control, loss

\section{Introduction}

On the basis of available sources of information to the head of the entity is necessary to make management decisions. An entity may have information as in large quantities, and is in its complete absence (Borodovsky, 2000). Thus, there are informational risks uncertainties. One of the sources of internal information is the accounting (financial) statements. It is in the process of formation of the accounting (financial) statements the most typical uncertainty of the economic environment. The consequences of this uncertainty are accounting risks. Analyzing the risks inherent in the Russian economy, it is possible to separate the two groups. The first group is standard risks (net). They are inherent to the economic entities in all economic activities. The second group will include dynamic risks (investment, commercial and other). Both groups of risks directly or indirectly affect accounting information.

For example, financial risks. All information about the financial position, financial results of the company contained in the financial statements. If inflation is insignificant, in this case, there is a strong influence on reporting. Due to the sharp appreciation of the dollar, inflation has a negative impact on all aspects of the activity and, accordingly, the financial statements become biased. Using this information, the analysis results and corresponding conclusions will be unreal. There is a situation in which the accounting statements do not provide an objective assessment of the real value of the assets and liabilities of the entity and requires appropriate adjustments for inflation. The cost of the asset and liabilities denominated in foreign currency shall be recalculated in rubles at the rate set by the Central Bank of the Russian Federation. The time lag between the business operations and the dynamics of exchange rates indicates the presence of uncertainty and risk of inaccurate information (Berezina, 2010). 
Analyzing information risks can be said that the objective and subjective randomness generate the essence of processes, objects, and other lines. If the objective is the randomness associated with natural matter, the subjective randomness is determined by the incompleteness of the causes of events. As a rule, risk situations subjective. The entity to receive information is limited to the tools, techniques. The accident is partly determined by the lack of quality information. Objective randomness adds information uncertainty, which is the essence of all risks. So how risks affect information system, lead the subject to damage, we can assume that information risks are economic.

For each subject there are always risks control outdoor events. The ambiguity of tax law leads to uncertainty and does not allow the taxpayer to do the right thing in dispute. Not knowing the position of the Supervisory authority, the subject runs the risk of being punished by penal sanctions, which involves risks. At the same time the subject uses the principle of overpayment of taxes that distort the validity of the information in the financial statements.

Along with risk control external events, the entity should consider the risks of force majeure, which can be caused as a subjective (explosion) and objective factors (heat), the results of which can be the destruction of the financial statements (Chorafas, 2007; Woods, Kajuter, \& Linsley, 2007).

Today the Russian accounting system completed the transition to reporting in accordance with the requirements of International financial reporting standards. While these standards outline General principles only and for specific circumstances, for example, the accounting object, explanations do not contain. Thus, the accountant must justify their actions at the level of "professional judgment" (Tolstova, 2008). And it is the emergence of the risk of human error. The analysis of the literature showed that a clear definition of "professional judgment" in scientific writer-the temperature is not present. In our opinion, the "professional judgment" is a useful, responsible decision of an independent expert, which made them on the basis of his qualifications and experience.

Regardless of the nature of the occurrence of any risks are reflected in your information and have a common component. This component should-know accounting risk. If violated accounting principles or not complied with, then, as a consequence of this uncertainty in the accounting (financial) statements, accounting information is distorted. Therefore, the cause of accounting risk is the uncertainty aspect which applies to all account information. While the circumstances of its origin are subjetive-objective character. On the one hand the risk of human error, on the other hand the disadvantages of accounting standards.

\section{Methods}

Using the methods of empirical knowledge is investigated and summarized the essence of economic risks in the face of uncertainty, detailed accounting category "risks" in the accounting entities. Using the methods of comparison identified the main causes of the accounting risks. Techniques of observation, detailing the necessity of making adjustments to the existing Russian system of accounting in the field of creation of reserves.

\section{Results and Discussion}

In the system of economic security of the entity, the accounting function requires a number of studies on the risks in accounting. All risks ultimately determine its place in the financial statements, are subject to accounting.

We believe that the financial risk should recognize the result of economic developments in conditions of uncertainty under the influence of subjective and objective factors influencing accounting information.

The main direct causes accounting risk, we believe the following:

1) Standard accounting methodology does not correspond to the specific activity of the enterprise;

2) Standard accounting methodology does not match the specifics of the enterprise;

3) Deficiencies in training;

4) An erroneous judgment in interpreting laws and regulations;

5) Domestic organizational and methodological basis of accounting does not comply with IFRS;

6) The erroneous judgment in the formation of accounting policies;

7) A significant time lag between the release of the normative document and the actual execution of it;

8) The statutory financial statements contain virtually no user information about the prospects of its activities.

Appropriate accounting risks of the entity are classified into three groups for the purpose of conducting analytical accounting. 
First group: accounting risks directly related to the specialization of the subject, namely:

- Investment risks;

-Risks of bankruptcy;

-Risks doubtful receivables;

-Risks related to liabilities directly associated with the production, maintenance contracts.

Second group: accounting risks directly unrelated to the subject of specialization, namely:

-Risks doubtful receivables;

-Risks of force majeure;

- The risk of impairment of assets as a result of a sharp rise in inflation;

- The risks of liabilities.

The third group: accounting risks that are associated with ensuring the reliability of accounting information, as follows:

- The risks of accounting organization;

-Risks associated regulations.

In order to balance the risk to reflect as an object of accounting it is necessary to identify, evaluate and reflect documented. For this purpose, it is necessary to develop information-registration maintenance of accounting risks, by which we mean the formation of internal accounting procedures for implementing risk in the SVK. Under SVK means a system of internal control, which includes the procedures and techniques used to identify significant errors that can affect the reliability of indicators of financial statements, their timely correction and prevention. Information and accounting software accounting risks in our view includes four components, namely:

-Regulating;

-Methodical;

-Analytical;

-Documentary.

Under the regulatory component will be to understand the regulations on accounting and reporting.

Methodological component includes the accounting (financial) statements, explanatory notes, audit reports, etc.

Analytical component is a set of tools, methods of risk analysis.

The documentary component involves the reflection of the results obtained after identification and risk assessment. The main objectives of the information and accounting software, we can see in the document information on the risks identified, their dynamics, the study of their impact on the reliability of the accounting (financial) statements, to prevent undesirable consequences, providing information, primarily for external users to attract investment. In the internal control system are the introductions of additional Department without extension administrative staff.

Functional elements include:

— Diagnosis of accounting information with the aim of identifying risks;

- The analytical procedure involves determining the probability of accounting risks, classifying, evaluating, and compiling their matrix to form reserves;

— The provisions under accounting risks;

- Control functions for proper use of reserves. The beginning of the research process involves the preliminary meeting, the staff survey, the collection of evidence, analysis of accounting (financial) reporting, analysis and design of the study results, the final meeting. The information obtained in the survey should be recorded. With this purpose it is proposed working document "Information sheet of the identified risks". The most important means of gathering information is an interview with the subsequent analysis of the results obtained from a number of employees. Evidence is objective, if they are confirmed by the facts. Great attention should be paid to the accounting policy of the company regarding compliance of formalities in content and substance, assessing the feasibility and suitability of the chosen methods of accounting, compliance with the conditions of economic activity. Analysis of organization of accounting involves testing for the presence of organizational, 
methodological, technical documentation; evaluation of the composition, level of education and frequency of change of accounting personnel; analysis of technical equipment used accounting software, documentation and all other information received suggests checking for the adequacy and objectivity. The identified discrepancies are subject to document and develop corrective measures nature. Research results and planned actions should be reflected in the working document "Certificate mismatch of the received information with the subsequent preparation of a working document "Certificate of identifiable accounting risks the third group of the analytical account". The structure of the proposed working document shown in Table 1.

Table 1. Structure of the working document "Certificate of identifiable accounting risks the third group of the analytical account"

\begin{tabular}{|c|c|c|c|}
\hline $\begin{array}{c}\text { The type and content of } \\
\text { risk }\end{array}$ & Plot accounting & Responsible & $\begin{array}{c}\text { Possible causes and } \\
\text { circumstances of } \\
\text { risk }\end{array}$ \\
\hline
\end{tabular}

The study on the first and second group of risks begins similarly with data collection and further analysis with the subsequent use of the collective methods of expert estimations ("Method of expert estimates", "Method round table" method "Commission"), an individual ("Delphi method", "Scenario method", method, "Interview"), conceptual approaches.

Identifiable risks are proposed to reflect the working paper: help on the identified accounting risks the first and second group of analytical accounting, the structure of which is shown in Table 2.

Table 2. Structure of the working document "Certificate identified accounting risks the first and second group of the analytical account"

\begin{tabular}{ccc}
\hline $\begin{array}{c}\text { The type and content of } \\
\text { risk }\end{array}$ & $\begin{array}{c}\text { The causes and } \\
\text { circumstances of risk }\end{array}$ & $\begin{array}{c}\text { Planned (corrective) } \\
\text { actions }\end{array}$ \\
\hline
\end{tabular}

On the basis of the identified risks and analysis of the nature of their occurrence, it is advisable to analyze changes in the accounts under their influence, followed by the preparation of accounting statement about the change in balance sheet items and their corresponding thereto applications. To this end, we offer account register "Certificate about changes in the accounts, under the influence of risks", the structure of which is shown in Table 3.

Table 3. Structure of the working document "Certificate about changes in the accounts, under the influence of risks"

\begin{tabular}{ccc}
\hline $\begin{array}{c}\text { The title and the } \\
\text { name of the account } \\
\text { balance }\end{array}$ & Data of accounting & Analytical data \\
\hline
\end{tabular}

The next stage involves the study of analytical parameters in the dynamics-based analysis of the forms of accounting (financial) statements, explanatory notes, and auditor's report. With this purpose it is necessary to practice analytical tables, which provide visibility of information, organize data, reducing the number of analytical reports. Depending on the specific activities of a company can be formed its own system of analytical indicators. If we consider the existing forms of the accounting (financial) statements, their content does not disclose the sources of financing assets. Analytical procedures permit an assessment of the financial and economic activities and make informed conclusions.

The use of factor analysis to identify cause-and-effect relationships and estimation of the importance of 
participating factors. Differential method, reception chain substitutions, taking the arithmetic difference of the integral method and the logarithmic method are deterministic techniques of factor analysis. It allows evaluating the influence of certain factors in deterministic models. Formed a system of measurable indicators should allow to obtain quantitative estimates of the financial status of enterprises. Financial risk is mathematically expressed by the probability of loss. This probability is based on statistical data. Assessment of accounting risks involves finding the dependency between the size of the losses and the likelihood of their occurrence. Knowing the possible consequences and their probability can be quantitatively determining the amount of accounting risk. For definition of probability quality and quantitative standards are used. For example, to assess the characteristics of the probability of accounting risks, you can use four groups of probability with a value in percent, namely:

-Unlikely $(0.26 \%)$;

- Likely (26-50\%);

-Possible (50-76\%):

-Expected (76-100\%).

The event will not happen, if the probability is equal to zero. The event will occur, if the probability is equal to one. To estimate possible losses, you can use a point system risk assessment, which is shown conventionally in Table 4.

Table 4. Accounting risks on the value of losses

\begin{tabular}{lllll}
\hline No. & Types of risk & The grade $\AA$ & In $\%$ of the planned profit & $\begin{array}{l}\text { The creation of a reserve } \\
\text { (Yeslno) }\end{array}$ \\
\hline 1. & Minimum & 1 & $0 \%<\AA \leq 10 \%$ & no \\
2. & Low & 2 & $10 \%<\AA \leq 30 \%$ & no \\
3. & Average & 3 & $30 \%<\AA \leq 50 \%$ & Yes $\backslash$ no \\
4. & High & 4 & $50 \%<\AA \leq 70 \%$ & Yes \\
5. & Very high & 5 & $70 \%<\AA \leq 100 \%$ & Yes \\
\hline
\end{tabular}

Within the methods of the system SVK materiality is determined, the probability and cost of risk. The conversion ratio risk-income to an acceptable value from the point of view of the company represents the optimization. The basis for making management decisions, which are reduced to the optimization, is the identification and assessment of risk. The rationale for the creation of reserves is the matrix of probability and amount of risk. The reservation system is the best way to protect against risk. There are two functional components of the reservation is to counter the negative external factors and compensation of possible negative consequences. The risk matrixes to create reserves to cover losses are shown in Table 5.

Table 5. The risk matrix to create reserves

\begin{tabular}{lllll}
\hline $\begin{array}{l}\text { The probability } \\
\text { Risk }\end{array}$ & Unlikely & Probable & Possible & Expected \\
Price risk & & & & \\
\hline Minimum & - & - & - & - \\
Low & - & - & + & + \\
Average & + & + & + & + \\
High & + & + & + & + \\
Very high & + & + & + & + \\
\hline
\end{tabular}

This approach allows you to adjust the profit with regard to possible losses. Accounting risks, we offer to evaluate on the planned amounts of loss. It is necessary to take into account such factors as cost increases and inflation. 
After assessing the accounting risk and its impact on the accounting (financial) statements found documenting the decision on the formation of reserves for transmission directly to the accounting Department. To this end, we proposed the preparation of a working document "The conclusion about the formation of reserves for accounting risks", which in our view consists of a table variant (Table. 6) and explanatory, on the basis of which prepares the order of the reflection in accounting of operations on the formation of reserves, the implementation of which should be documented in the working paper "the Report formed the reserves."

Table 6. The table fragment working document "The conclusion about the formation of reserves for accounting risks"

$\begin{array}{lll}\text { Types of accounting risks } & \begin{array}{l}\text { Size } \\ \text { accrual }\end{array} & \begin{array}{l}\text { Account for the impact } \\ \text { of reserves }\end{array}\end{array}$

\section{Group I}

accounting risks directly related to the specialization of the subject

93 "Provisions under accounting risks"

\section{Group II}

accounting risks not directly related to the specialization of the subject

93 "Provisions under accounting risks"

\section{Group III}

accounting risks that are associated with ensuring the reliability of accounting information
93 "Provisions under accounting risks"

\section{SVK provides:}

- Control features on the use of reserves;

-Assessment of the residual risk after the establishment of reserves for prior periods;

-Identify the benefits of implementing a system of risk in relation to the costs of their organization.

If the provision for risks is not planned, it is the programmer for the development of internal procedures for prevention.

The tasks of the control functions include:

-Accounting and the production of documents for inspection;

-Consulting;

- Timely informing of the performers on the timing of execution of documents;

- The assessment of redundancy and efficiency reserves. Between the management and the Supervisory authority are assumed to be backward and forward linkages. For example, in the case of certain deviations Supervisory authority reports to the supervisor about their unsatisfactory work. Division Manager, in turn, will try to avoid deviations from scheduled in the most efficient execution path of a document. All allowances are characterized by uncertainty in terms of its magnitude and therefore conditional. Accounting commercial entities assumes the principle of prudence. In practice, there are facts of economic activity that began in the previous reporting period, but are included in the statements for the reporting period. When reporting the actual full amount of the loss cannot count. Accountant, evaluating such effects need to be very careful. Caution determines the prudence principle, which in turn goes into uncertainty. Costs and revenues of the reporting period, we recognize assessment as it was formed on the basis of available financial information. Due to the influence of accounting risks real accounting amount is not consistent with the original assessment of the financial result, there occurs a difference that must be recognized as expenses at the time of formation of financial statements in accordance with the prudence principle. All this suggests the inevitability of allowance under the accounting risks.

Russian standards, as well as international does not provide for the establishment of reserves for accounting risks. In our opinion it is necessary to Supplement the chart of accounts of financial and economic activities of 
organizations" 93 "Provisions under accounting risks". Proposed correspondence accounts given in Table 6.

Table 7. Correspondence of accounts prepared on account 93 "Provisions under accounting risks"

\begin{tabular}{lccc}
\hline \multicolumn{1}{c}{ Contents of business operations } & $\begin{array}{c}\text { Debit } \\
\text { account }\end{array}$ & \multicolumn{2}{c}{ Credit } \\
& account \\
\hline Accrued reserve & 91.2 & 93 \\
Written-off balance (credit) & 93 & 91.1 \\
\hline
\end{tabular}

Analytical records must be kept in the context we proposed earlier groups, namely:

-The first group: accounting risks directly related to the specialization of the subject;

- Second group: accounting risks directly connected with the specialization of the subject;

-Third group: accounting risks that are associated with ensuring the reliability of accounting information.

Correspondence of accounts should be reflected in the log-warrant credited to the account "Provisions for accounting risks" and in the relevant statements of the analytical account. The forms of accounting registers are shown in Tables $7 \& 8$.

Table 8. The structure of the account register Log order by credit 93 "Provisions under accounting risks"

\begin{tabular}{|c|c|c|c|c|c|c|}
\hline \multirow[t]{2}{*}{$\begin{array}{l}\text { Name of analytical } \\
\text { accounting }\end{array}$} & \multicolumn{2}{|c|}{$\begin{array}{c}\text { Balance at the beginning } \\
\text { of the reporting month, } \\
\text { rubles }\end{array}$} & \multicolumn{2}{|c|}{$\begin{array}{l}\text { Turnover for the } \\
\text { reporting month, rubles }\end{array}$} & \multicolumn{2}{|c|}{$\begin{array}{l}\text { Balance at the end of the } \\
\text { reporting month, rubles }\end{array}$} \\
\hline & $\begin{array}{c}\text { Debit } \\
\text { account }\end{array}$ & $\begin{array}{l}\text { Credit } \\
\text { account }\end{array}$ & $\begin{array}{c}\text { Debit } \\
\text { account }\end{array}$ & $\begin{array}{l}\text { Credit } \\
\text { account }\end{array}$ & $\begin{array}{c}\text { Debit } \\
\text { account }\end{array}$ & $\begin{array}{l}\text { Credit } \\
\text { account }\end{array}$ \\
\hline $\begin{array}{l}\text { accounting risks } \\
\text { directly related to the } \\
\text { specialization of the } \\
\text { subject }\end{array}$ & - & - & - & - & - & - \\
\hline $\begin{array}{l}\text { accounting risks not } \\
\text { directly related to the } \\
\text { specialization of the } \\
\text { subject }\end{array}$ & - & - & - & - & - & - \\
\hline $\begin{array}{l}\text { accounting risks that } \\
\text { are associated with } \\
\text { ensuring the reliability } \\
\text { of accounting } \\
\text { information }\end{array}$ & - & - & - & - & - & - \\
\hline Total: & - & - & - & - & - & - \\
\hline
\end{tabular}


Table 9. The structure of the account register "Analytical account 93" "Provisions under accounting risks"

\begin{tabular}{llllll}
\hline The reporting period & $\begin{array}{l}\text { To the debit } \\
\text { accounts }\end{array}$ & & & $\begin{array}{l}\text { of account } \\
\text { period }\end{array}$ \\
\hline January & - & - & - & - & - \\
February & - & - & - & - & \\
march & - & & - & - & - \\
April & - & - & - & - & - \\
May & - & - & - & - & - \\
June & - & - & - & - & - \\
July & - & - & - & - & - \\
August & - & - & - & - & - \\
September & - & - & - & - & - \\
October & - & - & - & - & - \\
November & - & - & - & - & - \\
December & - & - & - & - & - \\
\hline
\end{tabular}

For effective risk management system of the business, according to the authors you suggested are the original registers to enter into the framework of the program "1C: Enterprise 8".

Section of the balance sheet Short-term liabilities is a recommended addition to the "Provisions under accounting risks".

According to the letters PZ-9/2012 of the Ministry of Finance of the Russian Federation "On information disclosure about the risks of economic activities of the organization in the annual financial statements, all entities of the business must provide information about the risks of material nature with the purpose of generating financial picture. Taking into account these requirements, we recommend that you enter in the explanatory note to the accounting statements section "Information on financial risks" (Tab. 9).

Table 10. The section "Information on financial risks"

\begin{tabular}{|c|c|c|c|c|c|}
\hline Name of indicator & Line code & Period & $\begin{array}{l}\text { At the beginning of } \\
\text { year }\end{array}$ & $\begin{array}{l}\text { Change } \\
\text { for the period }\end{array}$ & $\begin{array}{l}\text { At the end of } \\
\text { year }\end{array}$ \\
\hline $\begin{array}{l}\text { Provisions for } \\
\text { accounting risks total: }\end{array}$ & 10100 & 2014 & 112000 & 34000 & 78000 \\
\hline $\begin{array}{l}\text { accounting risks directly } \\
\text { related to the } \\
\text { specialization of the } \\
\text { subject }\end{array}$ & 10101 & 2014 & 54000 & -21000 & 33000 \\
\hline $\begin{array}{l}\text { accounting risks not } \\
\text { directly related to the } \\
\text { specialization of the } \\
\text { subject }\end{array}$ & 10102 & 2014 & 16000 & -6000 & 10000 \\
\hline $\begin{array}{l}\text { accounting risks that are } \\
\text { associated with ensuring } \\
\text { the reliability of } \\
\text { accounting information }\end{array}$ & 10103 & 2014 & 42000 & -7000 & 35000 \\
\hline
\end{tabular}


The inclusion in the financial statements commitments under accounting risks will testify to the evaluation of the real assets that will make financial statements more transparent for attracting investment.

Of course, many leaders in addressing risk reduction are proponents of outsourcing, relying on the main criterion - cost savings.

The possibility of solving internal issues with outsourcing in our opinion may lead to:

First: to leak trusted information;

Second: to solve the required tasks are not at that level of quality, want;

Thirdly: there is no guarantee that the outsourcer qualification is higher than that of existing staff in your organization that can perform the same work;

Fourthly: the outsourcers order to preserve clients can take several firms at the same time, overloading the performers that directly lead to error;

Fifthly: due to the different location between outsourcers-performers and client organizations leads to the violation of the efficiency of solving problems associated with the information;

Sixthly: the outsourcers in the right moment can simply disappear from the market along with trusted documents;

Seventh: the recourse to outsourcing leads to lower motivation of the personnel;

Eighth: analyzing accounting risks, outsourcing due to the remote operation will not cover some of the internal aspects of accounting experience, leading to uncertainty, for example, risks of the human factor;

Ninth: experts-outsourcers can deeply understand the required expertise, especially in insurance, where there is a complex specificity;

Tenth: a thorough analysis of the outsourcing companies in identifying accounting risks, and the subsequent establishment under these provisions puts the organization in the future dependence of the outsourcer-contractor.

Selected aspects, in our opinion result in additional accounting risks.

\section{Acknowledgements}

The author expresses his deep gratitude to the reviewers for detailed dis-watching the manuscript and valuable comments.

\section{References}

Berezina, A. (2010). Effect of economic risks for the accuracy of the financial statements. Vector science Togliatti State University, 3(13), 144-145.

Borodovsky, L., \& Lore, M. (2000). Professional's Handbook of Financial Risk Management. Hardbound.

Chorafas, D. (2007). Risk Accounting and Risk Management for Accountants. Imprint: Cima Publishing.

Khokhlov, N. (2007). Risk Management: Proc. Manual for Schools. Moscow.

Mathews, M., \& Perera, M. (1996). Accounting Theory and Development (3rd ed.). Melbourne: Thomas Nelson Australia.

Shedrov, V., \& Sevastianova, E. (1998). The Transformation of the Accounting System in the Russian Federation to Increase the Investment Attractiveness of Business Entities. Moscow.

Shevelev, A. (2007). Risks in Accounting: Textbook. Moscow.

Tolstova, A. (2008). Risk in business accounting. Bulletin of the Samara State University of Economics, 9(47), 94-97.

Welfens, J. (2011). Innovations in Macroeconomics. New York. http://dx.doi.org/10.1007/978-3-642-11909-5

Woods, M., Kajuter, P., \& Linsley, P. (2007). Systems, Internal Control and Corporate Governance. International Risk Management. 


\section{Copyrights}

Copyright for this article is retained by the author(s), with first publication rights granted to the journal.

This is an open-access article distributed under the terms and conditions of the Creative Commons Attribution license (http://creativecommons.org/licenses/by/3.0/). 